\title{
Government Domestic Debt, Private Sector Credit, and Crowding Out Effect in Oil-Dependent Countries
}

\author{
Anthony Anyanwu ${ }^{\mathrm{i}}$ \\ Lincoln University, New Zealand \\ Christopher Ganii \\ Lincoln University, New Zealand \\ Baiding Huiii \\ Lincoln University, New Zealand
}

\begin{abstract}
Banks are more liquid, better capitalised, and more profitable in oil-dependent countries. However, bank credit to the private sector is relatively low as a percentage of GDP. The low level has been blamed, amongst other reasons, on governments' reliance on the banking sector to finance fiscal deficits. This study examines the crowding out effect of government domestic borrowing using a panel data model for 28 oil-dependent countries over the period 19902012 . We estimate the model, using both fixed effects and generalised method of moments estimators and find that a one percent increase in government borrowing from domestic banks significantly decreases private sector credit by 0.22 percent and has no significant impact on the lending rate banks charge to the private sector. This finding suggests that government domestic borrowing has resulted in the shrinking of private credit and works through the credit channel and not the interest rate channel.
\end{abstract}

\footnotetext{
i) Department of Financial and Business Systems, P.O Box: 85013, Lincoln University, Christchurch, New Zealand, Tel: +64-221-989909; email: Amarachukwu.Anyanwu@lincolnuni.ac.nz

ii) Professor, Department of Business and Finance, Faculty of Commerce, Department of Accounting, Finance and Economics, PO Box 85084, Lincoln University, Christchurch, New Zealand, Tel: +64-3-423-0227; email: Christopher.Gan@Lincoln.ac.nz

iii) Senior Lecturer, Faculty of Agribusiness and Commerce, Department of Food and Resource Economics, Lincoln University, Christchurch, New Zealand, Tel: +64-3 423 0231; email: Baiding.Hu@Lincoln.ac.nz
}

The authors would like to thank the anonymous reviewers for their helpful and constructive comments. They would also like to thank the Editors for their generous comments and support during the review process

First received, February 1, 2017; Revision received, May 15, 2017; Accepted, June 14, 2017. 
Keywords: banks, liquidity, oil-dependent, crowding out, credit

JEL Classification: E02, G20, H63

\section{Introduction}

Banks intermediate funds from the surplus sector to the deficit sector of the economy. Banks are subject to certain regulations by the regulatory authorities but they influence the rules in allocating funds and thus play a significant role in determining the type of investment activities, the level of job creation and the distribution of income (Gross, 2001). The banking industry in oil-dependent ${ }^{1}$ countries has changed significantly buoyed by the natural resource sector, mergers and acquisitions, the advent of globalization and the emergence of technological advances in information and communication technologies. Banks in oil-rich countries ${ }^{2}$ are more liquid, more profitable, and better capitalised (Beck, 2011). However, they disburse less private credit than the non-oil countries. For instance, bank private credit from 2000-2011 on average in Azerbaijan and Nigeria were 11\% and 19\% of total GDP, respectively (oil-rich countries); whereas bank private credit in Tunisia and Bangladesh were $55 \%$ and $33 \%$ of total GDP, respectively (non-oil countries). In oil-rich Democratic Republic of Congo, over the same period, bank credit to the private sector accounts for less than 7\% of GDP (WDI, 2014). This is surprising given the massive amount of excess liquidity in the banking sector of oil-rich countries and reflects a weak level of financial intermediation.

One of the signs of economic development is the increasing role of the private sector. The level of domestic credit measures financial

\footnotetext{
${ }_{1}^{1}$ Algeria, Angola, Equatorial Guinea, Gabon, Nigeria, Cameroon, Chad, Congo Republic, Dem. Rep. Congo, Bolivia, Mexico, Trinidad, Ecuador, Venezuela, Saudi Arabia, Qatar, Syria, Kuwait, Iran, Yemen, Bahrain, Oman, Azerbaijan, Kazakhstan, Papua New Guinea, Indonesia, Malaysia, and Vietnam.

${ }^{2}$ A country is oil-rich if the average share of hydrocarbons in total fiscal revenue and/or total export is at least 25 percent. Source: http://www.imf.org/external/np/fad/trans/guide. htm, p. 2).
} 
resources provided to the private sector by banks and other financial entities. Credit is the oil that greases the private sector; for this reason, it is observed closely to assess economic growth. More credit to the private sector reflects more opportunity for the private sector to grow and develop. The higher this measure, the larger the private sector gets and the better is the health and development of the economy. The persistent talk in policy circles and the media has increasingly blamed government borrowing for the low level of private credit as governments rely on the banking sector to finance budget deficits. One of the common forms of crowding out happens when a government increases its domestic borrowing and because governments have the ability to borrow large amounts of money, doing so can potentially have a substantial impact on the real interest rate. This can suffocate the economy's lending capacity and thus hinder businesses from engaging in capital projects.

The effects of government borrowing can operate through different channels, however, many of the concerns have focused on the potential interest rate effect. Government borrowing can affect private investment by crowding out private sector credit directly (real crowding out), or indirectly through rising interest rates (financial crowding out), though the magnitude of these potential adverse consequences depends on the degree to which government borrowing raises interest rates and/ or reduces private credit (Engen and Hubbard, 2004). Nonetheless, the occurrence of one channel does not preclude the likelihood of the other. The analysis of the effects of government borrowing on private investment has been ongoing for more than three decades, empirical consensus about the transmission mechanism and magnitude differ given economic structure and regulatory constraints. Does government borrowing from domestic banks qualitatively drive up interest rates, or quantitatively shrink private sector credit? Unfortunately, both economic theory and empirical analysis have proved inconclusive. Our study is a modest attempt to bridge some of the gaps in the literature for the case of oil-dependent economies. 


\section{Literature Review}

\subsection{The interest rate channel}

The literature identifies two variants of crowding out: real and financial (Blinder and Solow, 1973). The real crowding out occurs when the increase in public investment displaces private capital formation, which is also called direct crowding out. Direct crowding out refers to the substitution relationship between public and private spending that occurs not through changes in prices, interest rates, or required rate of returns in the public sector, but through the public sector consumption and investment (Buiter 1990, p. 34). On the other hand, the phenomenon of partial loss of private capital formation in the economy due to increase in the interest rates stemming from the pre-emption of financial resources by the government through bond-financing of fiscal deficit, is termed financial crowding out, which is also known as indirect crowding out. Indirect crowding out is the consequences of public actions that affect private behaviour either by altering the budget constraints or by influencing the prices faced by private agents through the interest rate:

The standard benchmark for understanding the potential effect of changes in government borrowing on interest rates is a model based on an aggregate production function for the economy in which government debt crowds out productive physical capital ${ }^{3}$. In this simple model; interest rate ( $\mathrm{r}$ ) determined by the marginal product of capital (MPK), would increase if capital (K) decreased, or was crowded out, by government debt (D). The Cobb-Douglas production function is given as:

$$
Y=A K^{\sigma} L^{(1-\sigma)}
$$

Where L denotes labour units, A is the coefficient for multifactor productivity, and $\sigma$ is the coefficient on capital in the production func-

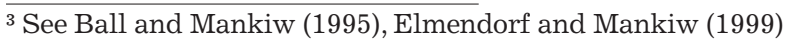


tion, then the total return to capital in the economy $\left(\mathrm{MPK}^{*} \mathrm{~K}\right)$ as a share of output (Y) equals:

$$
\sigma=(\mathrm{MPK} \times \mathrm{K}) / \mathrm{Y}
$$

The interest rate is determined by.

$$
\mathrm{r}=\mathrm{MPK}=\sigma \times(\mathrm{Y} / \mathrm{K})=\sigma \times \mathrm{A} \times(L / K)^{1-\sigma}
$$

If government debt completely crowds out capital, so that $\partial \mathrm{K} / \partial \mathrm{D}=$ -1 , then an exogenous increase in government debt (holding other factors constant) causes the interest rate to increase:

$$
\begin{aligned}
\partial \mathrm{r} / \partial \mathrm{D}= & (\partial \mathrm{r} / \partial \mathrm{K})(\partial \mathrm{K} / \partial \mathrm{D})=\sigma \times(1-\sigma) \times\left(\mathrm{Y} / K^{2}\right)>0 \\
& (\text { Because } 0<\sigma<1 \text { and } \mathrm{Y}, \mathrm{K}>0)
\end{aligned}
$$

The level of the interest rate is determined by the level of the capital stock and, thus, by the level of government debt. It is the change in the interest rate that is affected by the change in government debt. The aggregate effect of government borrowing on interest rate is viewed from different perspectives (Bahmani-Oskooee, 1999). First, the Neo-classical theory of interest rate argues that financing a budget deficit implies an increase in the supply of government bonds at a higher interest rate which discourages private investment and results in crowding-out. Second, the Keynesian theory asserts that expansionary fiscal policy will lead to little or no increase in the interest rate and instead an increase in output and income and hence a crowding-in rather than crowding-out (Aschauer, 1989). Third, the Ricardian equivalence theorem proposed by Barro (1974) advocates neutrality such that increase in the deficit financed by fiscal spending will be matched with a future increase in taxes leaving interest rates and private investment unchanged. A similar view is found in the Capital inflow hypothesis which is based on the idea that the demand for government debt is infinitely elastic (Dwyer, 1985). That is, an increase in the deficit will be financed partly or wholly not by domestic savings but an inflow of capital from abroad; if this hypothesis holds, interest rates could remain unchanged. 


\subsection{The credit channel}

In principle, government borrowing affects private investment through the lending rate, however in financially repressed economies ${ }^{4}$ particularly in many developing countries, the equilibrium interest rate could be somewhat insensitive to market perceptions. Reinhart et al. (2011) argue that government debts could have no effect on interest rates but have significant effect on private credit due to intervention by the government such as administrative controls imposed on interest rates, high legal reserve ratio, existence of direct intervention on credit allocation, government ownership or control of financial institutions, barriers that limit other institutions seeking to enter the market, or by moral suasion ${ }^{5}$. With the existence of these 'artificial' constraints, financial institutions will not take risks because higher interest rates cannot be charged which results in many high-yielding projects facing credit rationing (Fry 1988, p. 18). Hence, private credit will not be allocated according to the expected returns on the projects, but according to the quality of collateral, loan size, political pressure, and covert benefits to loan officers (King and Levine, 1993). The credit rationing behaviour of banks could also be a result of the weakness of the legal institutions in enforcing contracts (La Porta et al., 1998). In this case, interest rate variability will have no or at best a weak relationship with government borrowing. Thus, if the interest rate channel is weak, the quantity channel will capture the effects of government borrowing.

Consequently, the degree of quantitative crowding out depends on the nature of the endogenous response of the banks to higher government borrowing and how they alter their balance sheets. Banks respond to higher government borrowing by adjusting their loan portfolio optimally given the risk-return characteristics of different assets and liabilities (Emran and Farazi, 2009). First, if banks have excess liquidity, a higher degree of lending to the government may not result in any significant reduction of credit to the private sector. Second, access to safe government assets could allow the banks to take more

\footnotetext{
${ }^{4}$ Financial repressions are measures that governments employ to channel funds to themselves, which in a deregulated market would go elsewhere.

${ }^{5}$ Moral suasion is an unofficial persuasion tactic used by the government (i.e. the central bank) to influence and pressure banks into adhering to preferred policy.
} 
risk and thus increase their lending to the private sector which is the 'safe asset model' of which without the availability of public debt, borrowers could face higher borrowing costs (Kumhof and Tanner, 2005). Such endogenous response by banks could 'crowd-in' private credit or partially offset the traditional crowding-out effect. The third is the 'lazy bank model' which posits that a high degree of lending to the government may discourage banks from lending to the risky private sector and thus stifle their incentives to seek out new profitable investment opportunities in the private sector (Hauner, 2009). For instance, Ghana has been offering an interest rate of over 15 percent on its Treasury Bills in the last five years ${ }^{6}$. The high single-digit to double-digit returns could encourage banks to invest in government treasury bills as opposed to actual intermediation of funds to the private sector.

\subsection{Empirical studies}

Baldacci and Kumar (2010) examined the impact of public debt on interest rates for a panel of 31 advanced and emerging economies from 1980 to 2008 with a fixed-effect and system GMM approach and conclude that public debt leads to a significant increase in interest rates but this is greater in countries with weak initial fiscal conditions, weak or inadequate institutions, structural factors such as low domestic savings and limited access to global capital. The study by Aisen and Hauner (2013) estimated the impact of budget deficit on interest rate with the generalised method of moments (GMM) over a panel of 60 advanced and emerging economies from 1970-2006. The authors conclude that there was a significant positive impact of budget deficits on interest rates and only significant when deficits were high, or interact with high domestic debt, when financial openness was low, or financial depth was low. However, despite the greater attention given to developed economies, the economies with the highest interest rates and a history of fiscal mismanagement are in the developing countries. Akinboade (2004) investigates the budget deficit-interest rate relationships in South Africa, using the Granger-causality methods. The author's

$\overline{{ }^{6} \text { http://www.mofep.gov.gh/financial-news }}$ 
results suggest that budget deficits have no effect on interest rates in South Africa. Pandit (2005) examined the relationship between longterm nominal interest rate and budget deficit variables in Nepal for the period 1975-2003 and found evidence that there exists a positive but insignificant relationship. The author concludes that both the supply of and demand for long term government securities are not market based. Mukhtar and Zakaria (2008) investigated the relationship between interest rates and government deficits in Pakistan over the period 19602005 and found that government budget deficits did not exert significant influence on nominal or real interest rates. Chakraborty (2012) examined whether there is any evidence of financial crowding out in the recent years of financially deregulated interest rate regime in India. The author found no significant relationship between the two. Kelikume (2016) applied panel vector autoregression technique (PVAR) in 18 countries of sub-Saharan Africa (SSA) over the period 2000-2014 and concludes that interest rate response to government fiscal deficit is insensitive.

Credit markets rarely reach equilibrium through changes in interest rates alone (Temin and Voth, 2005). Thus, changes in the quantity of credit will give a better insight of the effect of government borrowing. Temin and Voth (2005) argue that examinations of interest rates are fundamentally misguided, and that the 18th- and 19th-century private loan market balanced through quantity rationing in England. The authors used a vector autoregressive (VAR) approach on lending volume at Hoare's Bank and conclude that there was substantial crowding out, that is, a $1 \%$ rise in government debt led to a $1 \%$ decline in private lending. Christensen (2005) regressed private sector lending on domestic debt in 27 sub-Sahara African countries over the period 1980-2000. The author's results shows significant support for the crowding-out hypothesis; an expansion in domestic debt of 1 percent relative to broad money causes the ratio of private sector lending to decline by 0.15 percent. Abdel-Kader (2006) conducted a survey of some state owned and private banks and 351 firms from various sectors in Egypt. The study investigates the extent of credit decline to the private sector in Egypt and whether it was due to supply factors (credit crunch), demand factors (credit slowdown), or other factors (e.g., crowding out). The study 
found that interest rates were no longer the decisive factor in lending decisions. A study by Emran and Farazi (2009) explored the crowdingout effect using panel data on 60 developing countries from 1975-2006. The estimates indicate that a $\$ 1.00$ more of government borrowing reduces private credit by $\$ 1.40$. De Bonis and Stacchini (2010) investigate the role of total government debt on the size of bank loans to the private sector in 20 emerging economies and the result shows that government debt reduces the size of private sector credit and low private credit is associated with a large size of government activities. Shetta and Kamaly (2014) used a VAR model on quarterly data spanning 19702009 to gauge the crowding out effect of government domestic borrowing on private credit in Egypt. The authors' estimates indicate that $\$ 1.00$ more of government borrowing reduces private credit by $\$ 1.80$. Ahmed (2016) estimated bank supply side equation in Pakistan using 3SLS from 1990-2013 and found that government borrowing leads to crowding credit away from possible productive use by the private sector. Choudhary et al. (2016) analyzed the pressure fiscal expansion exerts on the economy via credit markets in Pakistan from 1975-2008. The authors conclude that government borrowing leads to crowding out of private credit and rise in interest rate spreads.

This research study quantifies the effect of government domestic borrowing on lending interest rate and private credit in oil-dependent countries. Economies dominated by hydrocarbons possess certain characteristics not shared by other economies because their economic dynamics are mainly determined by the prices of oil and gas at world markets rather than by domestic economic activity, thus the volatility and uncertainty of resources revenues pose challenges for the design of appropriate policy framework.

\section{Data and Model Specification}

This study estimates the link between government borrowing from domestic banks and changes in private sector credit and lending rate for a panel of 28 oil-dependent countries. The compiled data is from the World Development Indicators database and used annual data 
spanning 1990-2012 $2^{7}$ The model is based on Emran and Farazi (2009) theoretical framework and equation (2) constitutes the specification of the empirical dynamic panel data.

$$
\mathrm{C}_{\mathrm{it}}=\rho \mathrm{C}_{\mathrm{i}, \mathrm{t}-1}+\beta \mathrm{X}_{\mathrm{it}}+u_{\mathrm{i}, \mathrm{t}}
$$

Where $\rho$ is a scalar such that $|\rho|<1 ; \rho$ is an unknown parameter of the lagged endogenous variable, $\beta$ is the unknown parameter vector of the $K$ exogenous variables, $X_{i, t}$ as row vector of explanatory variables with the dimension of $K=n \times 1$ with $n$ equals the number of exogenous variables, but it is acknowledged that these variables may not be exogenous, it has unobservable country-specific, time-invariant effects, $\left(v_{i}\right)$ and the residuals $\left(\varepsilon_{i t}\right)$, such that $u_{i, t}=v_{i}+\varepsilon_{i t}$. Where the residuals $\left(\varepsilon_{i t}\right)$ are white-noise such that the $\varepsilon_{i t} \sim \operatorname{IID}\left(0, \sigma_{\varepsilon}^{2}\right), v_{i} \sim \operatorname{IID}\left(\sigma_{v}^{2}\right), i=1,2,3, \ldots . . N$ is an index for individual sample of oil-dependent countries, where $N=$ $28, t=1,2,3, \ldots . T$ is an index for time-variant periods, in this case, years, so that $T=6$ for four-year average base estimation such as 1990-1993, 1994-1997, 1998-2001, 2002-2005, 2006-2009, 2010-2012 whilst $T=23$ for the estimations involving the study period, 1990-2012.

This model is based on the assumptions that (i) the error term is orthogonal to the exogenous variables so that $E\left(\mathrm{x}_{\mathrm{it}} \varepsilon_{\mathrm{it}}\right)=0$; (ii) the independently and identically distributed error terms are uncorrelated with the lagged endogenous variable implying that $E\left(\mathrm{C}_{\mathrm{it}-1} \varepsilon_{\mathrm{it}}\right)=0$; (iii) the exogenous variables might be correlated with the individual effect, for which reason $E\left(\mathrm{x}_{\mathrm{it}} \mathrm{V}_{\mathrm{i}}\right) \neq 0$; (iv) the past value is prone to affect the present such that $E\left(\mathrm{C}_{\mathrm{it}} \mathrm{C}_{\mathrm{i}, \mathrm{t}-1}\right) \neq 0$, so there is a need to capture the dynamic effects of the dependent variable and, (v) the country-specific effect and the disturbance error are independent of each other $E\left(v_{i} \varepsilon_{i t}\right)=0$.

Bank Private Credit and Domestic Lending Rate are the dependent variables. Bank credit issued to the private sector, is the credit provided by the banking system to the private sector as a percentage of GDP. This measure is better than other measures of financial development used in the literature because it is more directly linked to investment and growth (Calderón and Liu 2003, p. 326; Fitzgerald, 2006). Domes-

\footnotetext{
${ }^{7}$ It takes non-overlapping four-year averages to reduce the potential bias arising from having a large number of time observations in dynamic panel estimation. This is only for the generalized method of moments (GMM) estimations.
} 
tic lending rate measures the bank lending rate that usually meets the short- and medium-term financing needs of the private sector. Given that most interest rates are highly correlated, the commercial banks' lending rate is used as a proxy for the nominal interest rates (e.g. Bhalla, 1995).

Domestic Debt is the independent variable of interest which measures the claims on the central government by the domestic deposit money banks and other financial institutions. The sign for this variable is expected to be negative because an increase in government borrowing could crowd out private credit as espoused (e.g. Christensen, 2005), and it is expected to be positive for lending rate because increased government borrowing could potentially raise lending rate (e.g. Ford and Laxton, 1999).

The set of control variables ${ }^{8}$ embodied in $X_{i, t}$ are:

Per Capita GDP is included as an indicator of growth. We control for per capita income growth as rapidly growing economies are likely to have greater demand for and supply of credit (e.g. Djankov et al., 2007; Emran and Farazi, 2009).

Money Supply measures the sum of currency outside banks, demand deposits other than those of the central government, and the time, savings, and foreign currency deposits of resident sectors other than the central government. We control for this variable because an increase in the supply of money might lead to liquidity surges - thus to credit expansion.

Trade Openness is calculated as the ratio of the country's total trade; the sum of exports plus imports, to the country's gross domestic product. We control for this variable since a relatively open economy could dampen the effect of government borrowing.

Institutional Quality Index is included because better institutions are associated with more transparency and accountability, less corruption, and better protection of property rights. As a proxy for the quality of institutions, we use the Heritage Foundation's Index of Economic Freedom. This index aggregates 10 components with equal weight namely, trade policy, fiscal burden, government intervention, monetary policy, capital flows and foreign investment, banking and finance, prop-

${ }^{8}$ Trade Openness, Money Supply, Private Credit, and Government Domestic Debt are measured in constant 2005 U.S. dollars. The variables are in logs. 
erty rights, wages and prices, regulation, and black market. The index assigns a score (0-100) to each country's performance and higher scores correspond to higher levels of institutional quality. We control for this variable because better institutions is an important determinant of private credit (e.g. La Porta et al., 1997).

Inflation is included to account for macroeconomic stability. It is the growth rate of annual consumer price index (CPI). We control for this variable because high inflation distorts the credit allocation process and deteriorates credit quality which undermines the supply of loanable funds (e.g. Baum et al., 2009).

Price of Crude Oil is calculated using Brent Crude which serves as a major benchmark price for purchases of oil worldwide. Introducing the oil price index allows us to measure the impact that fluctuations in world oil price could have on the supply of loanable funds. We deflate this variable by CPI to obtain the real crude oil price. We control for this variable because an increase in the price of crude oil will result in a windfall and increase the supply of loanable funds. It could also dampen the effect of government borrowing on bank credit.

\section{Econometric Results}

\subsection{OLS and Fixed-effect: Government borrowing and private sector credit}

The basic model ${ }^{9}$ specifying the private credit from the banking sector is expressed as follows:

$$
\begin{aligned}
C_{i t}= & \alpha_{i}+\beta_{1} G_{i, t}+\beta_{2} Y_{i, t}+\beta_{3} F_{i, t}+\beta_{4} I_{i, t} \\
& +\beta_{5} O_{i, t}+\beta_{6} Q_{i, t}+\beta_{7} R_{i, t}+\varepsilon_{i, t}
\end{aligned}
$$

\footnotetext{
${ }_{9}$ We deviated from the bank specific factors such as overhead cost, competition, interest spread etc. These explanatory variables were omitted as we improvise the specification according to the purpose of the study which is to assess the role of government borrowing from domestic banks on private credit to understand the transmission channel of the crowding out phenomenon.
} 
Where $C$ is the log of real private credit as a percentage of GDP, $G$ is the log of real government borrowing as a percentage of GDP, $Y$ is the real GDP per capita growth rate, $F$ is the log of real level of financial debt, $I$ is the inflation rate expressed as a percentage, $O$ is the real price of crude oil, $Q$ is the institutional quality, $R$ is the lending rate expressed as a percentage, and $\varepsilon_{i, t}$ is the error term that includes all unobservable influences on private credit. The focus is on the parameter $\beta_{1}$; crowding out of private credit by government borrowing implies that $\beta_{1}<0$, while crowding in of private credit implies $\beta_{1}>0$. We present the fixed effect model results in Table 1 . The regression results shows that the effect of government borrowing on private credit is negative and statistically significant across all specifications.

Table 1. Determinants of private credit, 1990-2012

\begin{tabular}{|c|c|c|c|c|c|c|c|}
\hline & Privatecredit & Privatecredit & Privatecredit & rivatecredit & Privatecredit & Privatecredit & Privatecredit \\
\hline \multirow[t]{2}{*}{$\begin{array}{l}\text { Domes- } \\
\text { ticdebt }\end{array}$} & -0.372 & -0.276 & -0.275 & -0.190 & -0.190 & -0.192 & -0.204 \\
\hline & $(10.83)^{* *}$ & $(15.03)^{* *}$ & $(14.95)^{* *}$ & $(10.12)^{* *}$ & $(10.12)^{* *}$ & $(9.95)^{* *}$ & $(9.36)^{* *}$ \\
\hline \multirow{2}{*}{$\begin{array}{l}\text { Money- } \\
\text { supply }\end{array}$} & & 0.653 & 0.641 & 0.679 & 0.666 & 0.660 & 0.623 \\
\hline & & $(38.92)^{* *}$ & $(32.37)^{* *}$ & $(34.22)^{* *}$ & $(27.96)^{* *}$ & $(26.66)^{* *}$ & $(22.42)^{* *}$ \\
\hline \multirow[t]{2}{*}{ Oilprice } & & & 0.172 & & 0.153 & 0.147 & 0.096 \\
\hline & & & (1.18) & & (1.02) & $(0.93)$ & $(0.45)$ \\
\hline \multirow[t]{2}{*}{ InstQ } & & & & 3.729 & 3.649 & 4.374 & 4.350 \\
\hline & & & & $(4.10)^{* *}$ & $(3.99)^{* *}$ & $(4.23)^{* *}$ & $(3.42)^{* *}$ \\
\hline \multirow[t]{2}{*}{ Inflation } & & & & & & 0.024 & -0.063 \\
\hline & & & & & & (1.19) & (1.59) \\
\hline \multirow{2}{*}{$\begin{array}{l}\text { GDPper- } \\
\text { capita }\end{array}$} & & & & & & & 0.472 \\
\hline & & & & & & & $(4.52)^{* *}$ \\
\hline \multirow[t]{2}{*}{$\begin{array}{l}\text { Lendin- } \\
\text { grate }\end{array}$} & & & & & & & 1.630 \\
\hline & & & & & & & $(2.47)^{*}$ \\
\hline \multirow[t]{2}{*}{ _cons } & 273.197 & 29.576 & 26.737 & -190.973 & -188.429 & -224.958 & -264.513 \\
\hline & $(37.11)^{* *}$ & $(4.01)^{* *}$ & $(3.44)^{* *}$ & $(3.79)^{* *}$ & $(3.73)^{* * *}$ & $(3.97)^{* *}$ & $(3.64)^{* *}$ \\
\hline $\mathrm{R}^{2}$ & 0.17 & 0.77 & 0.77 & 0.79 & 0.79 & 0.79 & 0.80 \\
\hline $\mathrm{N}$ & 620 & 620 & 619 & 452 & 452 & 429 & 363 \\
\hline
\end{tabular}

The dependent variable is real private credit.

All variables are in log, except oil price, institutional quality, inflation, lending rate and GDP per capita growth rate

The model is estimated with fixed-effect estimator with * and ** indicating significant at the 5 and 1 per cent level.

Source: Author's estimations 
In other words, when government borrows $\$ 1$ from domestic banks, it crowds out private credit by $\$ 0.20$. The fixed-effect estimator mitigates the omitted variable problems by drawing fixed effects out of the error term. However, the estimates could be biased due to endogeneity arising from simultaneity as private and public credit are mostly determined by the highest achievable performance of the banks given regulatory constraints. Then again, reverse causality might be trivial given the dominance of governments in oil-rich economies.

\subsection{OLS and Fixed-effect: Government borrowing and lending interest rate}

The basic model ${ }^{10}$ specifying the lending rate to the private sector is expressed as follows:

$$
\begin{aligned}
R_{i t}= & \alpha_{i}+\beta_{1} G_{i, t}+\beta_{2} Y_{i, t}+\beta_{3} F_{i, t}+\beta_{4} I_{i, t} \\
& +\beta_{5} O_{i, t}+\beta_{6} Q_{i, t}+\beta_{7} C_{i, t}+\varepsilon_{i, t}
\end{aligned}
$$

The focus is on the parameter $\beta_{1}$; crowding out by government borrowing in relation to lending rate implies that $\beta_{1}>0$, while crowding in implies $\beta_{1}<0$. We used the fixed-effect panel regression on pooled data $^{11}$. The estimated coefficients for equation (4) is presented in Table 2 . The regression results shows that the effect of government borrowing on lending interest rate is negative and statistically insignificant. The fixed-effect estimator improves the OLS model by mitigating the omitted variable problems; however, the estimates could be affected by endogeneity resulting from a loop of causality between the lending interest rate and government borrowing. Again, this could be negligible

\footnotetext{
10 We have not drawn heavily on the determinants of interest rate model such as government consumption, private consumption, private savings, etc. This omitted variables are not required for our analysis as we improvise the specification according to our purpose which is to assess the role of government borrowing in the lending rate to understand the transmission channel of the crowding out effect

11 The Hausman test rejects the hypothesis that the individual effects are uncorrelated with the other regressors for the baseline model at the 1-percent level. Thus we use the fixed effect model.
} 
given the relatively strong grip of governments on domestic banks in the oil-rich economies.

Table 2. Determinants of lending interest rate, 1990-2012

\begin{tabular}{|c|c|c|c|c|c|c|c|}
\hline & Lendingrate & Lendingrate & Lendingrate & Lendingrate & Lendingrate & Lendingrate & Lendingrate \\
\hline \multirow[t]{2}{*}{$\begin{array}{l}\text { Domes- } \\
\text { ticdebt }\end{array}$} & -0.020 & -0.035 & -0.040 & -0.044 & -0.045 & -0.053 & -0.031 \\
\hline & $(0.75)$ & (1.31) & (1.57) & $(1.32)$ & $(1.40)$ & $(3.05)^{* *}$ & $(1.60)$ \\
\hline \multirow[t]{2}{*}{$\begin{array}{l}\text { Money- } \\
\text { supply }\end{array}$} & & -0.086 & 0.029 & -0.100 & 0.021 & -0.010 & -0.098 \\
\hline & & $(3.64)^{* *}$ & (1.02) & $(3.00)^{* *}$ & $(0.53)$ & $(0.45)$ & $(2.82)^{* *}$ \\
\hline \multirow[t]{2}{*}{ Oilprice } & & & -0.160 & & -0.142 & -0.098 & -0.104 \\
\hline & & & $(6.90)^{* *}$ & & $(4.99)^{* *}$ & $(6.16)^{* *}$ & $(6.54)^{* *}$ \\
\hline \multirow[t]{2}{*}{ InstQ } & & & & -0.555 & -0.459 & 0.030 & -0.033 \\
\hline & & & & $(3.37)^{* *}$ & $(2.86)^{* *}$ & $(0.31)$ & $(0.34)$ \\
\hline \multirow[t]{2}{*}{ Inflation } & & & & & & 0.051 & 0.051 \\
\hline & & & & & & $(30.44)^{* *}$ & $(30.61)^{* *}$ \\
\hline \multirow{2}{*}{$\begin{array}{l}\text { GDP- } \\
\text { capita }\end{array}$} & & & & & & & 0.123 \\
\hline & & & & & & & (1.43) \\
\hline \multirow[t]{2}{*}{$\begin{array}{l}\text { Bank- } \\
\text { credit }\end{array}$} & & & & & & & 0.123 \\
\hline & & & & & & & $(2.84)^{* *}$ \\
\hline \multirow[t]{2}{*}{ _cons } & 17.804 & 21.237 & 23.421 & 52.489 & 48.360 & 18.753 & 21.669 \\
\hline & $(31.05)^{* *}$ & $(19.29)^{* *}$ & $(21.24)^{* *}$ & $(5.71)^{* *}$ & $(5.40)^{* *}$ & $(3.50)^{* *}$ & $(3.98)^{* *}$ \\
\hline $\mathrm{R}^{2}$ & 0.00 & 0.03 & 0.11 & 0.06 & 0.12 & 0.76 & 0.77 \\
\hline $\mathrm{N}$ & 543 & 543 & 542 & 408 & 408 & 386 & 386 \\
\hline
\end{tabular}

The dependent variable is nominal lending interest rate

All variables are in log, except oil price, institutional quality, inflation, lending rate and GDP per capita growth rate

The model is estimated with fixed-effect estimator with * and ** indicating significant at the 5 and 1 percent level.

Source: Author's estimations

\subsection{Dynamic OLS and Endogeneity}

We employ dynamic OLS as represented in equation (2) to check for endogeneity arising from simultaneity (i.e. by adding the lagged dependent variable to see if it acts as a regressor). The result shows (in Table 3) the adjusted $\mathrm{R}^{2}$ increases from static to dynamic OLS which reflects the presence of reverse causation (Wintoki et al., 2012). If the lag terms belong there, then they should be included to avoid bias. The 
results shows "Private credit L.1" and "Lending rate L.1" are statistically significant at the $1 \%$ level respectively which means past values of private credit and lending rate explain significant variations in current values and thus confirms dynamic relationships. A dynamic process modelled with a static model is invariably misspecified and therefore incorrect (Keele and Kelly, 2006). There are numerous ways to address endogeneity: (i) the Structural Equation Modelling (SEM); (ii) the Two Stage Least Square (2SLS) regression model; and (iii) the Generalized Method of Moments (GMM) estimators. The first two require valid external instruments which are difficult to obtain (Flannery and Hankins, 2013; Wintoki et al., 2012). Because of the lack of valid external instruments suitable in a panel setting, the system-GMM estimator approach proposed by Blundell and Bond (1998) is the most suitable method to deal with endogeneity issues that arises from the dynamic nature of the model. The s-GMM estimator deals with several problems encountered in estimating dynamic panel models, such as endogeneity, measurement errors and omitted variable bias.

Table 3. The effect of government domestic debt on private credit and lending rate

\begin{tabular}{l|c|c|c|c}
\hline \multirow{2}{*}{} & \multicolumn{2}{|c|}{ Static Models } & \multicolumn{2}{c}{$\begin{array}{c}\text { Dynamic Models } \\
\text { OLS }\end{array}$} \\
\cline { 2 - 5 } & Private Credit & Lending Rate & Private credit & Lending Rate \\
\hline & & & & \\
Private credit L.1 & & & $0.765^{*}(0.000)$ & \\
Lending rate L.1 & & & & $0.628^{*}(0.000)$ \\
Domestic debt & $-0.147^{*}(0.000)$ & $0.028(0.051)$ & $-0.091^{*}(0.000)$ & $0.016(0.140)$ \\
Money supply & $0.725^{*}(0.000)$ & $-0.071^{*}(0.004)$ & $0.190 *(0.000)$ & $0.053^{* *(0.011)}$ \\
Price of crude oil & $0.109(0.675)$ & $-0.050^{*}(0.001)$ & $0.054(0.710)$ & $0.030(0.056)$ \\
InstQ & $0.183^{* *(0.044)}$ & $-0.253^{*}(0.000)$ & $0.018(0.718)$ & $-0.101(0.069)$ \\
Inflation & $-0.074(0.159)$ & $0.055^{*}(0.000)$ & $-0.044(0.146)$ & $0.029 *(0.000)$ \\
GDP Per Capita & $0.143^{* *}(0.032)$ & $-0.137^{*}(0.003)$ & $0.090^{* *}(0.019)$ & $-0.092(0.104)$ \\
Lending rate & $0.157(0.053)$ & & $-0.096(0.058)$ & \\
Private credit & & $0.062(0.053)$ & & $0.0529(0.057)$ \\
Constant & -137 & 30 & -114 & 19.9 \\
$\mathrm{~N}$ & 363 & 386 & 360 & 377 \\
$\mathrm{R}^{2}$ & 0.77 & 0.68 & 0.98 & 0.79 \\
\hline
\end{tabular}

This table presents results of static and dynamic OLS. Asterisk * and ** indicate significance at $1 \%$ and $5 \%$.

P-values are reported in parenthesis. Source: Author's estimations. 


\subsection{Difference and System Generalised Method of Moments}

We apply generalised method of moments (GMM) dynamic panel estimator ${ }^{12}$ and utilize the following model specification:

$$
\mathrm{C}_{\mathrm{it}}=\rho \mathrm{C}_{\mathrm{i}, \mathrm{t}-1}+\beta \mathrm{X}_{\mathrm{it}}+u_{\mathrm{i}, \mathrm{t}}
$$

In equation (5), we control for endogeneity of the variables using internal instruments. The system-GMM estimation approach is to take the first differences to remove unobserved time-invariant countryspecific effects, and instrument the right-hand variables in the first differenced equations using levels of the lagged two periods or more. The s-GMM combines this set of equations with an additional set of equations in levels with lagged first-differences as instruments.

Table 4. Base model-system-GMM dynamic panel-two step robust estimate

\begin{tabular}{l|c|c|c|c}
\hline & \multicolumn{3}{|c|}{ Private Credit } & $\begin{array}{c}\text { Lending Rate } \\
\text { SYS-GMM }\end{array}$ \\
\cline { 2 - 4 } Constant & D-GMM & SYS-GMM & D-GMM & $86.69^{* *}$ \\
& -782 & -77.39 & -8.65 & $(0.016)$ \\
Private Credit L.1 & $(224)$ & $(0.563)$ & $(-1.99)$ & \\
Lending Rate L.1 & 0.261 & $0.725^{* *}$ & & \\
& $(0.110)$ & $(0.018)$ & & $0.521^{* *}$ \\
Domestic Debt & & & 0.895 & $(0.050)$ \\
& & & $(1.704)$ & -0.033 \\
Money Supply & $-0.191^{* *}$ & $-0.221^{* *}$ & -0.051 & $(0.257)$ \\
Oil Price & $(0.036)$ & $(0.031)$ & $(0.263)$ & -0.125 \\
& $0.534^{* *}$ & $0.318^{* *}$ & -0.367 & $(0.109)$ \\
Inst. Quality & $(0.047)$ & $(0.032)$ & $(-0.075)$ & -0.038 \\
& 0.674 & $0.236^{* *}$ & -0.075 & $(0.642)$ \\
& $(0.811)$ & $(0.045)$ & $(0.162)$ & -0.148 \\
& 0.812 & $0.602^{* *}$ & -0.082 & $(0.155)$ \\
\hline
\end{tabular}

12 There are 28 countries $(\mathrm{N})$ analysed over a period of 23 years $(\mathrm{T})$ and as a result there are more countries $(\mathrm{N})$ than years $(\mathrm{T})$. The dynamic panel model is designed for a situation where ' $T$ ' is smaller than ' $N$ ' in order to control for dynamic panel bias. However, for long panels (i.e. small $\mathrm{N}$ and large $\mathrm{T}$ ), the fixed effect estimator may be a better choice because its bias decreases as more periods are added (Nickel, 1981). Based on these reasons we present both the fixed-effect and GMM estimation results. 


\begin{tabular}{l|c|c|c|c}
\hline Inflation & -0.017 & -0.023 & $0.049^{* * *}$ & $0.043^{* * *}$ \\
& $(0.094)$ & $(0.538)$ & $(0.001)$ & $(0.000)$ \\
Lending Rate & -0.801 & -0.695 & & \\
& $(0.256)$ & $(0.627)$ & & \\
Private Credit & & & 0.094 & 0.157 \\
& & & $(0.061)$ & $(0.155)$ \\
GDP Per Capita & 0.063 & 0.105 & 0.282 & -0.009 \\
& $(0.070)$ & $(0.052)$ & $(0.115)$ & $(0.913)$ \\
Countries & 28 & 28 & 28 & 28 \\
Observations & 148 & 148 & 145 & 145 \\
No. of instruments & 18 & 26 & 16 & 24 \\
Hansen J- test & 0.847 & 0.866 & 0.506 & 0.661 \\
Diff. in Hansen & 0.265 & 0.924 & 0.678 & 0.999 \\
test & & & & \\
2nd Order & 0.703 & 0.482 & 0.397 & 0.359 \\
Correlation & & & & \\
\hline
\end{tabular}

P-values in parenthesis, ${ }^{* * *},{ }^{* *}$, denote statistical significance at the $1 \%, 5 \%$ level.

Source: Author's estimations

The validity of the estimates in s-GMM depends on the statistical diagnostics $^{13}$. The s-GMM allows for heteroscedasticity in the data which it can control (Baltagi, 2008). Small sample size causes serious problem with s-GMM; the standard errors in the two-step approach are biased downwards and needs to be corrected for (Windmeijer, 2005). We apply the so-called 'Windmeijer correction' which is Stata command 'small' to obtain robust standard errors for the coefficient estimates.

The results of relevant statistical tests and checks for s-GMM are:

1) The GMM estimator requires that there is first-order serial correlation AR (1) but no second-order serial correlation AR (2) in the residuals (Arellano and Bond, 1991). It means one could reject the null hypothesis in the AR (1) test but do not reject in the AR (2) test. Our results satisfy this test condition: 0.48 and 0.359 for private credit and

13 The s-GMM estimates are better than the D-GMM estimates when variables exhibit random-walk (Bond 2002; Roodman 2006). Our model specification includes macroeconomic variables with random walk, as a result, differencing the variables could remove variables that are persistent, such as lending rate. The s-GMIM produces more efficient and precise estimates than the D-GMM by improving precision and reducing the finite sample bias (Baltagi, 2008). The D-GMM estimator has the weakness of magnifying gaps with an unbalanced panel (Roodman, 2006, p.19). Though our panel is balanced, the s-GMM estimates provides better statistical diagnostics than the D-GMM. 
lending rate in the $\mathrm{AR}(2)$ test respectively.

2) The Hansen J-statistic tests the null hypothesis that the model specification is correct and all over-identifying restrictions are valid i.e. validity of instruments (Baum, 2006). The rejection of the null hypothesis means the estimates are unreliable. The Hansen test of over identifying restrictions does not reject the null $(p=0.86 ; p=0.66)$ for private credit and lending rate respectively.

3) Roodman (2006) suggests checking for 'steady-state' assumption to investigate further the validity of instruments. The estimated coefficient on the lagged dependent variable in the model should indicate convergence by having a value less than absolute unity (Roodman 2006, p. 43) otherwise the s-GMM estimates are invalid. The estimated coefficients of our lagged dependent variables are 0.72 and 0.52 respectively, which means the steady-state assumption holds.

4) Bond (2002) suggests additional checks on the validity of the estimates by checking if the estimated coefficient on the lagged dependent variable falls in between the values obtained from OLS and FE estimators. The results show: for private credit: $\mathrm{OLS}=0.76>\mathrm{GMM}=0.72$ $>\mathrm{FE}=0.51$. For lending rate: $\mathrm{OLS}=0.62>\mathrm{GMM}=0.52>\mathrm{FE}=0.49$ ). Hence, our estimates satisfy these conditions.

5) The Difference-in-Hansen test evaluates the validity of subsets of instruments (i.e levels, differenced, and the standard IV instruments). The null hypothesis of this test is that specified variables are proper instruments, i.e. the set of examined instruments is exogenous. We do not reject the null hypothesis of exogeneity of the GMM instruments.

6) Roodman (2007) suggests the number of instruments should not exceed the number of observations, which is the case here (26 instruments $<148$ observations for interest rate; 24 instruments $<145$ observations for private credit). Furthermore, an estimate with a perfect Hansen J-statistic sign (i.e. a p-value equal to 1.00) is questionable; the p-value should have a higher value than 0.25 (Roodman 2007, p. 10). Our Hansen J-test reports a p-value of 0.86 and 0.66 respectively, which satisfy this condition.

Next, we move to an economic explanation of the results reported in Table 4. The first variable of interest (Domestic Debt) is negative and statistically significant at the 5 percent level; there is some crowding out effect on private credit by government domestic borrowing of (-0.22) 
in absolute value which is much smaller than the (-1.4) recorded by Emran and Farazi (2009) in a panel of 60 developing countries. It is also significantly smaller than the (-1.8) reported for Egypt (Shetta and Kamaly, 2014). There could be several reasons for this; one might be due to the banking structure in oil-rich countries because banks in resourcebased economies tend to display higher profitability and are more liquid and better capitalized. Then, if banks have excess liquidity, a higher lending to the government may not result in any significant reduction of credit to the private sector. Second, banks in oil-rich economies disburse a small amount of private credit to the private sector, that is, the banks are already ineffective in channelling resources to the private sector, thus, increased government borrowing could have a smaller effect on the already small bank credit. Third, resource firms have better access to global financial markets because government ownership often play a big role in the resource sector (Wolf, 2009). Therefore, the resource sectors' access to international loan markets might contribute to the excess liquidity in the banking sector and thus mitigate government borrowing from crowding out banks' lending to the private sector.

The second variable of interest (Lending Rate) is statistically insignificant; government domestic borrowing does not affect the lending rate banks charge to the private sector. The reason for the insensitive interest rate in oil-rich countries could be the increasingly competitive nature of the domestic financial system, though unlikely given the high profitability of the banks. It might also be a result of the integration among international financial markets, though disputable since financial integration is associated with features like a liquid equity market, a lower cost of capital, and good credit ratings; a rarity in these countries. It is very likely the financial markets are underdeveloped and/ or governments exert some control on domestic banks since loans are typically not given according to the expected returns on the projects but based mostly on non-market considerations. 


\section{Conclusions}

This study shows that government domestic borrowing has a significant negative effect on private credit but it does not result in an increase in the interest rate charged by banks on loans to the private sector. These research results are important for understanding the mechanism through which government borrowing affects private investment because private investment depends critically on the availability of private credit, hence, crowding out of private credit may have significantly disadvantageous effects on private investment and consequently on economic growth. These results have some policy implications.

The effect of government domestic debt in oil-dependent countries is 'substantial' though smaller than results recorded in other developing countries and thus shows the peculiar nature of oil-dependent economies. However, substantial and persistent levels of government debt can cause downward pressure on domestic loanable funds and hence hinder private investment. The importance of developing and maintaining strong institutions to control spending, manage debt and maximize domestic revenue collection cannot be overemphasized. There is no significant change in lending rates as a result of government domestic borrowing, therefore governments in oil-rich countries should not be overly concerned about whether domestic borrowing affects lending rates, but rather focus on the levels of financial intermediation because the quantity of credit seems to change without a concomitant increase in the interest rate.

The oil and gas industry dominates economic activities and seems to have better access to finance than the other sectors. So, when government borrows from domestic banks, the burden of crowding out falls heavily on sectors that struggle to access domestic credit and on borrowers that cannot borrow internationally, usually the non-oil sectors. It means the non-oil sector suffers most from the increased government borrowing on the already thin loanable funds. That being the case, governments need to consider the potential implications of increased internal borrowing on the burden of crowding-out the financially con- 
strained sectors.

The key macroeconomic variables in oil-rich economies display a high degree of volatility; revenue, debt and spending are highly correlated with the global crude oil price. Hence, policymakers are encouraged to build up a liquidity fund (i.e. sovereign wealth fund) in good times that can be tapped to smooth government spending when resource revenues fall short. Without the sovereign wealth fund, or even with depleting reserve funds, oil-rich economies will resort to borrowing from domestic banks which will exacerbate the already meagre loanable funds available to the private sector.

Our results are interesting: government domestic borrowing has resulted in the shrinking of private credit and this works through the credit channel and not through the interest rate channel.

\section{References}

Ahmed, J.,"Credit Conditions in Pakistan: Supply Constraints or Demand Deficiencies?"The Developing Economies 54(2), 2016, 139-161.

Arellano, M. and S. Bond, "Some tests of specification for panel data: Monte Carlo evidence and an application to employment equations,"Review of Economic Studies 58, 1991, 277-297.

Abdel-Kader, K., "Private Sector Access to Credit in Egypt: Evidence From Survey Data,"Working Paper No. 111. The Egyptian Center for Economic Studies, 2006.

Aschauer, D. A., "Does Public Capital Crowd Out Private Capital?" Journal of Monetary Economics 24, 1989, 171-188.

Akinboade, O. A., "The relationship between budget deficit and interest rates in South Africa: some econometric results," Development Southern Africa 21(2), 2004, 289-302.

Aisen, A. and D. Hauner, "Budget deficits and interest rates: a fresh perspective," Applied Economics vol. 45(17), 2013, 2501-2510.

Bahmani-Oskooee, M., "Do Federal Budget Deficits Crowd Out or Crowd In Private Investment," Journal of Policy Modelling 21(5), 1999, 633640 . 
Buiter, W., Principles of Budgetary and Financial Policy. MIT Press, Cambridge, Massachusetts, 1990.

Blinder, A. and R. Solow, "Does Fiscal Policy Matter?" Journal of Public Economics, 1973, 319-337.

Beck, T., "Finance and Oil: Is There a Resource Curse in Financial Development?" Tilburg, The Netherlands: Tilburg University, 2011.

Blundell. R. and S. Bond, "Initial conditions and moment restrictions in dynamic panel data models," Journal of Econometrics 87, 1998, 115143.

Bond. S.,"Dynamic panel data models: a guide to micro data methods and practice,'The Portuguese Economic Journal 1, 2002, 141-162.

Baum, F. C., An Introduction to Modern Econometrics Using Stata, Texas: Stata Press, 2006.

Baum, F. C., Caglayan M. and N. Ozkan,"The second moments matter: the impact of macroeconomic uncertainty on the allocation of loanable funds,"Economic Letters 102, 2009, 87-89.

Barro, R. J., "Are Government Bonds Net Wealth?" Journal of Political Economy, 82, 1974, 1095-1117.

Baltagi, B. H., Econometric Analysis of Panel Data, Chichester: John Wiley \& Sons Ltd, 2008.

Bhalla, S., "This Time, It Is Already Different: A Personal Perspective," Deutsche Bank, December 7,1995

Christensen, J., "Domestic Debt Markets in Sub-Saharan Africa," IMF Staff Papers 52 (3), 2005, 518-38.

Choudhary, M.A., Khan, S., Pasha, F. and M. Rehman, "The dominant borrower syndrome," Applied Economics 48 (49), 2016, 4773-4782.

Calderon, C. and L. Liu, "The Direction of Causality between Financial Development and Economic Growth," Journal of Development Economics 72, 2003, 321-334.

Chakraborty, L., "Interest Rate Determination in India: Empirical Evidence on Fiscal Deficit- Interest Rate Linkages and Financial Crowding Out," Economics Working Paper 744, The Levy Economics Institute, NewYork, 2012.

Djankov, S., McLiesh, C. and A. Shleifer, "Private Credit in 129 Countries," Journal of Financial Economics 84 (2), 2007, 299-329.

De Bonis, R. and M. Stacchini, "What Determines the Size of Bank Loans in Industrialized Countries? The Role of Government Debt,"Work- 
ing Papers No.39, Money and Finance Research Group, 2010. Dwyer, G.P., "Federal Deficits, Interest Rates and Monetary Policy,'Journal of Money, Credit, and Banking 18, 1985, 655-681.

Emran, M.S, and S. Farazi, "Lazy Banks? Government Borrowing and Private Credit in Developing Countries," Institute for International Economic Policy: The George Washington University, 2009.

Engen, E.M. and G.R. Hubbard, "Federal Government Debt and Interest Rates," NBER Macroeconomics Annual 19, National Bureau of Economic Research, 2004, 83-138.

Flannery, M.J. and K.W. Hankins, "Estimating dynamic panel models in corporate finance," Journal of Corporate Finance 19 (C), 2013, 1-19.

FitzGerald, V., "Financial Development and Economic Growth: Critical View," Background paper for World Economic and Social Survey, Oxford University, 2013.

Fry, M., Money, Interest and Banking in Economic Development. Johns Hopkins University Press: Baltimore, MD, London,1998.

Ford, R. and L. Douglas, "World Public Debt and Real Interest Rates," Oxford Review of Economic Policy 15(2), 1999, 77-94.

Gross, M.D., "Financial Intermediation: A Contributing Factor to Economic Growth and Employment," Economic Development and Cultural Change 15(3), 2001, 257-268.

Greene, W., Econometrics Analysis. Upper Saddle River, New Jersey: Prentice Hall, 2008

Hauner, D., "Public Debt and Financial Development," Journal of Development Economics 88, 2009, 171-183.

Kumhof, M. and E. Tanner, "Government Debt: A Key Role in Financial Intermediation," IMF Working Paper WP/05/57, 2005.

Keele L. and N. J. Kelly, "Dynamic Models for Dynamic Theories: The Ins and Outs of Lagged Dependent Variables," Political Analysis 14(2), 2006, 186-205.

King, R. G. and R. Levine, "Finance and Growth: Schumpeter Might Be Right," The Quarterly Journal of Economics 108(3),1993, 717-37.

Kelikume, I., "The effect of budget deficit on interest rates in the countries of sub-Saharan Africa: A panel VAR approach,"The Journal of Developing Areas 50 (6), 2016, 105-120.

La Porta, R., Lopez-de-Silanes, F., Shleifer, A. and R.Vishny, "Legal determinants of external finance," Journal of Finance 52, 1997, 1131-50. 
Mukhtar, T. and M. Zakaria,"Budget Deficits and Interest Rates: An Emprical Analysis for Pakistan," Journal of Economic Cooperation 29(2), 2008, 1-14.

Nickel, S. J., "Biases in Dynamic Models with Fixed Effects," Econometrica $49,1981,1417-1426$.

Pandit, R., "The Impact of Fiscal Deficit on Long-term Nominal Interest Rate in Nepal," Economic Review, Occasional Paper No. 17, Nepal Rastra Bank, Kathmandu, 2005

Roodman, D., "How to do xtabond2: An Introduction to 'Difference' and 'System' GMM in STATA," Working Paper No. 103, Center for Global Development, 2006.

Roodman, D., "A Note on the Theme of Too Many Instruments,"Working Paper No.125, Center for Global Development, 2007.

Reinhart, C. M., Kirkegaard, J. F. and B. Sbrancia, "Financial repression redux,"Finance and Development 48(2), 2011, 22-6.

Shetta, S. and A. Kamaly, "Does the Budget Deficit Crowd-out Private Credit from the Banking Sector? The Case of Egypt," Topics in Middle Eastern and African Economies 16(2), 2014, 251-279.

Temin, P. and H-J. Voth, "Credit rationing and crowding out during the industrial revolution: evidence from Hoare's Bank, 1702-1862," Explorations in Economic History, Elsevier 42(3), 2005, 325-348.

Wintoki, M., Linck J. and J. Netter, "Endogeneity and the Dynamics of Internal Corporate Governance," Journal of Financial Economics 105(3), 2012, 581-606.

WDI (2014), World Development Indicators Database, http://data.worldbank.org/data-catalog/world-development-indicators. Retrieved on 16th March, 2016.

Wolf, C." "Does ownership matter?The performance and efficiency of State Oil vs. Private Oil (1987-2006)," Energy Policy 37(7), 2009, 26422652

Windmeijer, F.,"A Finite Sample Correction for the Variance of Linear Efficient Two-step GMIM Estimators," Journal of Econometrics 126(1), 2005, 25-51. 